\title{
Effect of Diesel Fuel Temperature on the Nitrogen Oxides Emission from a Compression-Ignition Engine
}

\author{
Mirosław Czechlowski ${ }^{1 *}$, Weronika Gracz ${ }^{2}$, Damian Marcinkowski², \\ Wojciech Golimowski ${ }^{3}$, Jakub Mazurkiewicz ${ }^{1}$
}

1 Faculty of Agronomy and Bioengineering, Poznań University of Life Sciences, ul. Wojska Polskiego 28, 60-637 Poznań, Poland

2 Department of Biomass processing Technologies, Institute of Technology and Life Sciences, ul. Biskupińska 67, 60-463 Poznań, Poland

3 Wroclaw University of Economics and Business, Department of Agricultural engineering and Quality Analysis, ul. Komandorska 118/120, 53-345 Wrocław, Poland

* Corresponding author's e-mail:m.czechlowski@up.poznan.pl

\begin{abstract}
The research aimed at analysing the influence of the diesel oil temperature on the $\mathrm{NO}_{\mathrm{x}}$ emission level. The tests were carried out on a test stand equipped with a $9.5 \mathrm{~kW}$ multi-fuel compression-ignition engine. The setup constitutes an experimental cogeneration unit discharging the produced energy into the power grid. The measurements were carried out under the D1 test procedure provided by ISO 8178-4 for testing engines operating at a constant speed. As a result of statistical analysis of the results obtained, significant differences were found in the u specific values of the nitrogen oxides emission gained for particular phases of D1 tests, when the engine was fed with diesel fuel of different temperatures. The results obtained confirmed the possibility of limiting the specific emission of $\mathrm{NO}_{\mathrm{x}}$ only when the engine is running at $75 \%$ of its nominal torque. An increase in the $\mathrm{NO}_{\mathrm{x}}$ emissions was recorded for the remaining loads.
\end{abstract}

Keywords: compression-ignition engine, $\mathrm{NO}_{\mathrm{x}}$ emissions, fuel temperature

\section{INTRODUCTION}

Internal combustion engines are still used as the primary source of propulsion for mobile machines; simultaneously, they are also responsible for the emission of toxic air pollutants. One of the most harmful compounds present in the exhaust gas corresponds to nitrogen oxides $\left(\mathrm{NO}_{\mathrm{x}}\right)$. As a result of the improved efficiency of diesel engines, achieved by increasing the pressure and temperature in the cylinders, the $\mathrm{NO}_{\mathrm{x}}$ concentration in the exhaust gases also increased significantly. The use of exhaust gas aftertreatment systems reducing the emission of particulate matter $(\mathrm{PM})$ and $\mathrm{NO}_{\mathrm{x}}$ has become obligatory, enforced by the combustion emission standards adopted in the USA and Europe [Blakeman et al. 2003]. The first solutions used to reduce the $\mathrm{NO}_{\mathrm{x}}$ emissions were the exhaust gas recirculation (EGR) systems
[Kouremenos, Hountalas, and Binder 2001; Hountalas et al. 2006; Kono, Kobayashi, and Takeda 2005]. Due to the increasingly restrictive regulations, the reduction of the $\mathrm{NO}_{x}$ emissions has been the subject of many ongoing studies. As a result, it was found that the catalysts for exhaust gas purification or biofuels used instead of conventional fuels are effective methods for reducing the emission of harmful gases [Hochhauser 2009; Johnson 2014].

The use of catalysts with platinum $(\mathrm{Pt})$ and rhodium ( $\mathrm{Rh}$ ) coatings has yielded very good results under stabilized conditions, even in the presence of sulphur. The $\mathrm{NO}_{\mathrm{x}}$ reduction efficiency reached $80 \%$ [Uekusa et al. 2003]. Different configurations of several serially operating catalysts were studied. They have been proven to work at low exhaust temperatures below $200^{\circ} \mathrm{C}$, which is difficult to achieve with traction engines 
[Tsukamoto et al. 2012]. Adsorption catalysts are deactivated over time by filling them with the molecules separated from exhaust gases. This problem has been solved by using a catalytic diesel particulate filter (CDPF), which cleans itself automatically as a result of a richer fuel mixture (Colliou et al. 2004). Another solution for the maintenance-free catalyst is a selective catalytic reduction (SCR), which requires atomisation of the urea solution (AdBlue) in the exhaust gas. Urban cycle tests showed a $60 \% \mathrm{NO}_{\mathrm{x}}$ reduction efficiency achieved by SCR [Saito et al. 2003]. The concept of combining the SCR catalysts with DPF was also developed. A new catalytic system called CRDPF was tested. The advantage of this solution is the high efficiency and versatility of systems for various types of diesel engines [Conway et al. 2005, Hosoya et al. 2007]. An alternative to the use of the AdBlue solvent is an NSR system with afterburning of the exhaust gas in a catalytic system, using an additional dose of fuel. Positive results have been obtained, but this solution generates an increase in the fuel consumption [Tsumagari et al. 2006]. One of the maintenancefree solutions that do not require additional catalyst power is the DPNR system. Its efficiency of $99 \% \mathrm{NO}_{\mathrm{x}}$ reduction has been confirmed in D1 simulation tests for power generators [Parthiban and Jain 2019, Ohashi et al. 2008].

Another solution is to modify the fuel or replace it with the fuels from renewable sources. Adding water in the form of emulsion with the fuel, or injecting it directly into the cylinder, results in a significant reduction in the nitrogen oxide emissions [Hountalas et al. 2006]. The replacement of diesel fuel by rapeseed oil methyl esters (RME) in an engine equipped with NSR/ DPNR/Oxidation catalysts has increased the $\mathrm{NO}_{x}$ emissions [Kawano et al. 2006]. This result was confirmed by other tests carried out on the engines not equipped with $\mathrm{NO}_{\mathrm{x}}$ reducing catalysts [Veltman, Karra, and Kong 2009]. Moreover, the use of FAME-type biofuels from various oils, including waste cooking oils (WCO) results in an increase in the $\mathrm{NO}_{\mathrm{x}}$ emission [Okamoto et al. 2010, Gysel et al. 2014]. In the case of replacing the diesel fuel by untreated rapeseed oil and hydrogenated rapeseed oil (HVO), the $\mathrm{NO}_{\mathrm{x}}$ emissions also increased with the rise in engine load. At the same time, a decreasing proportion of $\mathrm{NO}_{2} / \mathrm{NO}_{x}$ [Czerwinski et al. 2008, Mizushima et al. 2012] and NO/ $\mathrm{NO}_{x}$ were observed [Wu et al. 2017].
The use of efficient exhaust aftertreatment systems generates additional costs in the production and subsequent operation of engines. These costs, particularly in the case of the units with relatively low horsepower, may be difficult for buyers to accept. At the same time, the introduction of alternative fuels does not bring the expected results. For these reasons, the study aimed at changing the parameters of the diesel fuel injected into the cylinder of the diesel engine was undertaken. The first modification applied involved preheating the fuel and assessing the effect of the temperature changes on the level of emitted $\mathrm{NO}_{x}$. The study is inspired by the results indicating a reduction in the $\mathrm{NO}_{\mathrm{x}}$ emissions from diesel engines using pre-heated biofuels, such as vegetable oils, animal fats and vegetable oil esters [Kleinová et al. 2011; Ranjith, Velmurugan, and Thanikaikarasan 2019].

\section{MATERIALS AND METHODS}

\section{Test bench and procedures}

The tests were carried out using the ATMX 2000 engine dynamometer, which is a laboratory cogeneration unit equipped with Yanmar 2TNV70-ASA engine (Fig. 1). The engine is a naturally aspirated, two-cylinder unit with indirect injection and a displacement of $570 \mathrm{~cm}^{3}$. The engine uses a head with pre-combustion chambers, and its nominal power is $10.2 \mathrm{~kW}$ achieved at $3600 \mathrm{rpm}$. The setup is controlled by an automatic control and measurement system operated by Parm PC software. The electricity produced by the setup during the tests was transferred to the electrical grid through an inverter system.

The VARIOplus Industrial exhaust gas analyser manufactured by MRU was used to measure the concentration of nitrogen oxides ( $\mathrm{NO}$ and $\mathrm{NO}_{2}$ ) in the exhaust gas. The device is equipped with a heated probe wire to ensure correct measurements. The measurement of $\mathrm{NO}$ and $\mathrm{NO}_{2}$ concentrations is performed by the analyser using electrochemical sensors. The measurement of the exhaust gas flow is carried out by means of a Pitot tube placed in a measuring exhaust channel of known diameter. The ranges of the measured values are listed in Table 1.

The measurements were carried out according to ISO 8178-4 standard, following the D1 test intended for stationary engines operating at 


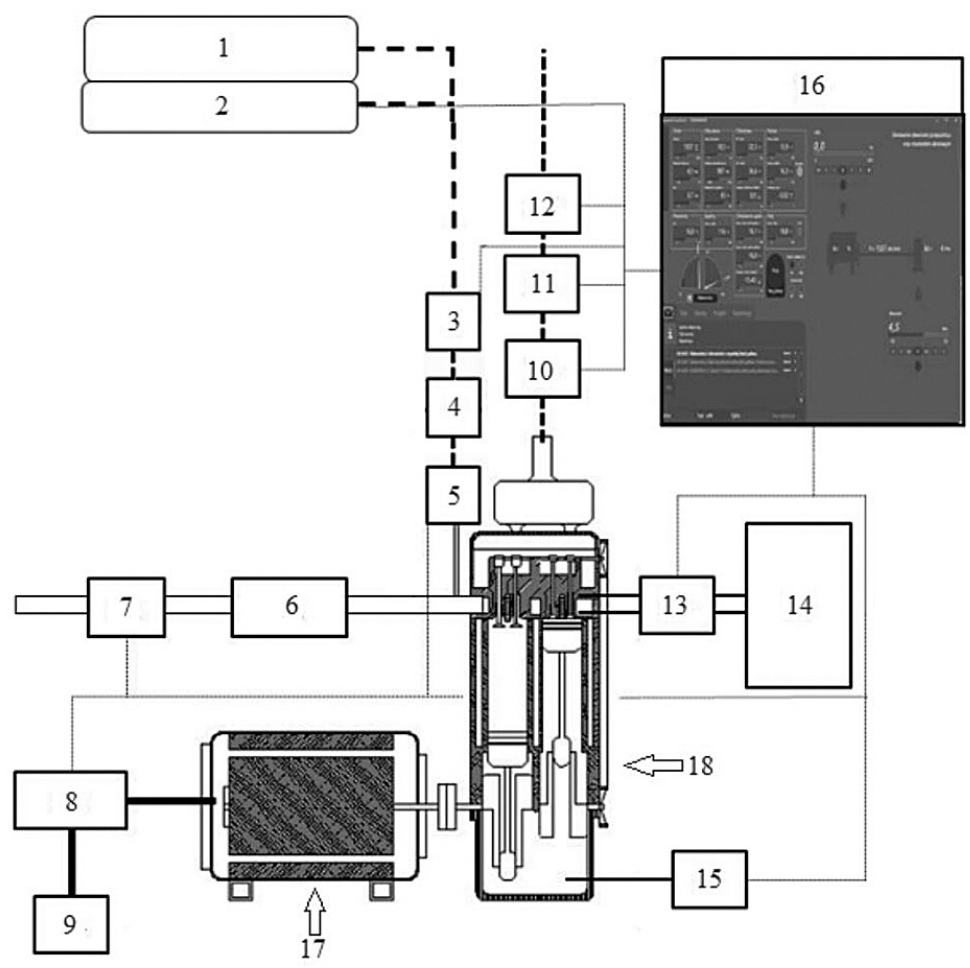

Fig. 1. Test bench: 1 - diesel oil tank, 2 - alternative fuel tank, 3 - fuel mass flowmeter, 4 - fuel temperature control system, 5 - fuel temperature sensor, 6 - air filter, 7 - temperature, pressure and humidity measurement, 8 - electric control and measurement system, 9 - electrical grid, 10 - exhaust gas temperature sensor, 11 - exhaust gas analyzer, 12 - exhaust gas volume flowmeter, 13 - heat measurement, 14 - cooling system, 15 - oil temperature sensor, 16 - measurement and control system, 17 - asynchronous electric motor, 18 - Yanmar 2TNV70-ASA engine [own elaboration based on Gracz 2018]

a constant speed. The D1 test consists of three measurement phases during which the engine operates under the corresponding load: $50 \%$, $75 \%$ and $100 \%$ of the nominal torque. For the Yanmar 2TNV70-ASA engine and the cogeneration unit nominal speed of $3000 \mathrm{rpm}$, these load levels correspond to torques of 14.0, 21.0 and $28.0 \mathrm{Nm}$, respectively. Each phase of the D1 test lasts 10 minutes. The measurement is carried out for the last 3 minutes of the phase, and a period of 7 minutes before the start of data recording is designed to stabilise the engine parameters. During each measurement, the data on the concentrations of nitrogen oxides were recorded 35 times, with sampling every $5 \mathrm{~s}$.

The measurements were taken three times, each time carrying out a D1 test for a different temperature of fuel supplied to the engine. The following fuel temperatures were used during the tests: 20,40 and $55^{\circ} \mathrm{C}$. These temperatures are achieved by heating the fuel with a laboratory heat exchanger. It was supplied with water of appropriate temperature prepared by a laboratory thermostat with a microprocessor controller. The fuel temperature measurement was carried out using a temperature sensor installed directly in front of the injection pump. This sensor is connected to the measuring system of the dynamometer.

During the research, Ekodiesel ULTRA diesel oil, produced by the Polski Koncern Naftowy Orlen, was used as engine fuel. This fuel meets the requirements of the standard PN-EN 590 and may contain up to $7 \%$ bio-components.

Table 1. Selected measuring ranges of the VARIOplus Industrial exhaust gas analyser

\begin{tabular}{|c|c|c|c|}
\hline \multicolumn{2}{|c|}{ Measured parameter } & Measuring range & Measuring error \\
\hline NO & nitrogen oxides (II) & $\begin{array}{c}0-1000 \mathrm{ppm} \\
\text { Overload } 5000 \mathrm{ppm}\end{array}$ & $\begin{array}{c} \pm 5 \mathrm{ppm} \text { or } 5 \%<1000 \mathrm{ppm} \\
10 \%>1000 \mathrm{ppm}\end{array}$ \\
\hline $\mathrm{NO}_{2}$ & nitrogen oxides (IV) & $\begin{array}{c}0-200 \mathrm{ppm} \\
\text { Overload } 1000 \mathrm{ppm}\end{array}$ & $\begin{array}{c} \pm 5 \text { ppm or } 5 \%<200 \text { ppm } \\
10 \%>200 \text { ppm }\end{array}$ \\
\hline \multicolumn{2}{|c|}{ Exhaust gas flow speed } & $1-100 \mathrm{~m} / \mathrm{s}$ & $\pm 1 \mathrm{~m} / \mathrm{s}$ or $3 \%$ measured value \\
\hline
\end{tabular}




\section{Data processing}

The analysis of the obtained results had to be started with determining the total concentration of nitrogen oxides in the exhaust gases. To this end, the values obtained for the $\mathrm{NO}$ and $\mathrm{NO}_{2}$ concentrations must be added together by the following equation:

$$
S_{N O_{x i}}=S_{N O_{2 i}}+S_{N O_{i}}
$$

where: $S_{\text {NOxi }}-$ total concentration of $\mathrm{NO}_{\mathrm{x}}$ $\left[\mathrm{mg} / \mathrm{nm}^{3}\right]$,

$S_{\mathrm{NO} 2 \mathrm{i}}-\mathrm{NO}_{2}$ concentration in the exhaust $\left[\mathrm{mg} / \mathrm{nm}^{3}\right]$,

$S_{\mathrm{NOi}}-\mathrm{NO}$ concentration in the exhaust $\left[\mathrm{mg} / \mathrm{nm}^{3}\right]$.

Second, the average values of total $\mathrm{NO}_{\mathrm{x}}$ concentration were determined for each phase of the D1 test.

$$
\overline{S_{N O_{x}}}=\frac{\sum S_{N O_{x i}}}{n}=\frac{S_{N O_{x 1}}+S_{N O_{x 2}}+. .+S_{N O_{x n}}}{n}
$$

where: $\overline{S_{N O_{x}}}$ - average of the total $\mathrm{NO}_{\mathrm{x}}$ concentration from each phase of the D1 test $\left[\mathrm{mg} / \mathrm{nm}^{3}\right]$,

$S_{N O \times 1,} S_{N O \times 2, \ldots,} S_{N O x n}-$ total concentration of $\mathrm{NO}_{\mathrm{x}}$ values for each data record $\left[\mathrm{mg} / \mathrm{nm}^{3}\right]$, $\eta$ - number of records stored for each test phase.

For the values obtained using the abovementioned procedure, the Fisher test was carried out to confirm that the averages of the aggregated $\mathrm{NO}_{x}$ emissions obtained for different fuel temperatures differ statistically significantly. To this point, homogeneity of variance tests and variance analysis were performed. Then, detailed hypotheses were made. The null hypothesis, assuming that the averages do not differ significantly from each other, and the alternative hypothesis indicating significant differences in average values:

$$
\begin{gathered}
H_{0 i i,}: \mu_{i}-\mu_{\mathrm{i}^{\prime}}=0 \quad \mathrm{i}, \mathrm{i}^{\prime}=1,2,3 \\
H_{1 i i^{\prime}}: \sim H_{0 i i^{\prime}}, \quad i \neq i^{\prime}
\end{gathered}
$$

The next step in the emission assessment, according to ISO 8178-4, was to compare the obtained average cumulative $\mathrm{NO}_{\mathrm{x}}$ concentration values with the power generated by the engine during each phase of the D1 test. This resulted in specific emissions expressed in $\mathrm{g} \cdot(\mathrm{kWh})^{-1}$.
The calculations were carried out using the following formula:

$$
N_{N O_{X}}=\frac{\overline{S_{N O_{x}}} \cdot \dot{V}}{P \cdot 1000}
$$

where: $N_{N O x}-\mathrm{NO}_{\mathrm{x}}$ specific emissions $\left[\mathrm{g} \cdot(\mathrm{kWh})^{-1}\right]$, $\dot{V}$ - exhaust gas volume flow $\left[\mathrm{nm}^{3} \cdot \mathrm{h}^{-1}\right]$, $P$ - engine power [kW].

The final result of the D1 test is a weighted average of the $\mathrm{NO}_{\mathrm{x}}$ emissions from all test phases calculated using the equation below:

$$
\begin{gathered}
N_{N O_{x D 1}}={\overline{S_{N O_{x}}}}_{50 \%} \cdot W_{50 \%}+{\overline{S_{N O_{x}}}} . \\
\cdot W_{75 \%}+\overline{S_{N O_{x}}}{ }_{100 \%} \cdot W_{100 \%}
\end{gathered}
$$

in which weighting factors $\mathrm{W}_{50 \%} ; \mathrm{W}_{75 \%}$ and $\mathrm{W}_{100 \%}$ take values: $0.30 ; 0.50$ and 0.20 ; respectively.

All the above-mentioned calculations, except the Fisher test, were made using the Microsoft Excel 2016 spreadsheet. The statistical tests were carried out using the Statistica 13.1 software package.

Finally, it was assumed that both: the specific emissions from the individual phases of test D1 and the final results of the weighted average from the whole test will be the basis for the assessment of the effect of the fuel temperature on the $\mathrm{NO}_{\mathrm{x}}$ emissions.

\section{RESULTS}

As it was mentioned earlier, the tests were carried out for three temperatures of fuel supplied to the engine injection system $(20,40$ and $55^{\circ} \mathrm{C}$ ) and for three different levels of engine load (50, 75 and $100 \%$ of nominal torque). In total, nine measurement cycles were performed. The results were divided into three groups, depending on the engine torque load. For the data from each group, the average total $\mathrm{NO}_{\mathrm{x}}$ emissions from each phase of the D1 test were determined and then the Fisher test was performed. In all 3 cases, with the assumed level of significance $\lambda=0.05$, the obtained statistic values prevented assuming the null hypothesis, with equal average values of $\mathrm{NO}_{x}$ emissions, as true. This allowed assuming an alternative hypothesis that the average $\mathrm{NO}_{x}$ emission values are statistically significantly different - as true. On this 
basis, it can be concluded that the changes in the temperature of the fuel supplied to the engine injection system have a significant impact on the $\mathrm{NO}_{\mathrm{x}}$ emissions.

The statement above allowed for a more accurate assessment of the impact of the fuel temperature changes on the $\mathrm{NO}_{\mathrm{x}}$ emissions. For this purpose, the results of the specific emission from the individual phases of the D1 test are shown in Figure 2. The first conclusion, which naturally appears when analysing the graph below, is that the changes in the fuel temperature have a much smaller effect on specific $\mathrm{NO}_{\mathrm{x}}$ emissions than the changes in engine load. This is because the increase in the engine load from 50\% to $100 \%$ results in reducing the specific $\mathrm{NO}_{\mathrm{x}}$ emissions almost in half.

On the other hand, only one case of a positive influence of the fuel temperature increase on the $\mathrm{NO}_{\mathrm{x}}$ emissions was found. It occurred when the engine was running at a load corresponding to $75 \%$ of the nominal torque. In this case, the increase in the fuel temperature from 20 to $55^{\circ} \mathrm{C}$ has reduced the specific $\mathrm{NO}_{\mathrm{x}}$ emissions from $10.18 \mathrm{~g} \cdot(\mathrm{kWh})^{-1}$ to $9.86 \mathrm{~g} \cdot(\mathrm{kWh})^{-1}$, which corresponds to a change of just over $3 \%$. For the other two torque loads, the temperature increase resulted in a proportional escalation in the $\mathrm{NO}_{\mathrm{x}}$ emissions. Thus, for a load of $50 \%$, an increase in the fuel temperature from 20 to $55^{\circ} \mathrm{C}$ caused a rise in the emissions of $0.09 \mathrm{~g} \cdot(\mathrm{kWh})^{-1}$, or $0.6 \%$ in relative terms. The intensification in the $\mathrm{NO}_{\mathrm{x}}$ emissions associated with increasing fuel temperature while the engine is running at full load is much more noticeable. In this case, a temperature increase of $35^{\circ} \mathrm{C}$ resulted in a rise in specific emissions of $0.95 \mathrm{~g} \cdot(\mathrm{kWh})^{-1}$. In relative terms, this corresponds to an increase in emissions of almost $14 \%$.

Since the final results of the D1 test are most influenced by the phase in which the engine runs at $75 \%$ load, it is still necessary to analyse the averaged results, as shown in the diagram below. Moreover, in the case of these results, the increase in specific $\mathrm{NO}_{x}$ emissions associated with higher engine fuel temperatures is clearly visible. However, in reality, it ranges between 0.14 and $0.20 \mathrm{~g} \cdot(\mathrm{kWh})^{-1}$, which means an increase does not exceed $2.0 \%$.

The results obtained during the course of the research indicate that the achievements of previous experiments, which confirmed the possibility of reducing $\mathrm{NO}_{\mathrm{x}}$ emissions by preheating the biofuel supplied to the engine, cannot be directly transferred to the engines fuelled with standard diesel oil. [Kleinová et al. 2011; Ranjith, Velmurugan, and Thanikaikarasan 2019]. However, comparing the obtained results of specific emission with the results of the works on a similar subject [Pielecha 2001, Piaseczny and Władyka 2008], it can be concluded that the influence of diesel oil preheating on the $\mathrm{NO}_{x}$ emissions is determined by the engine design and power achieved from $1 \mathrm{dm}^{3}$ of displacement.

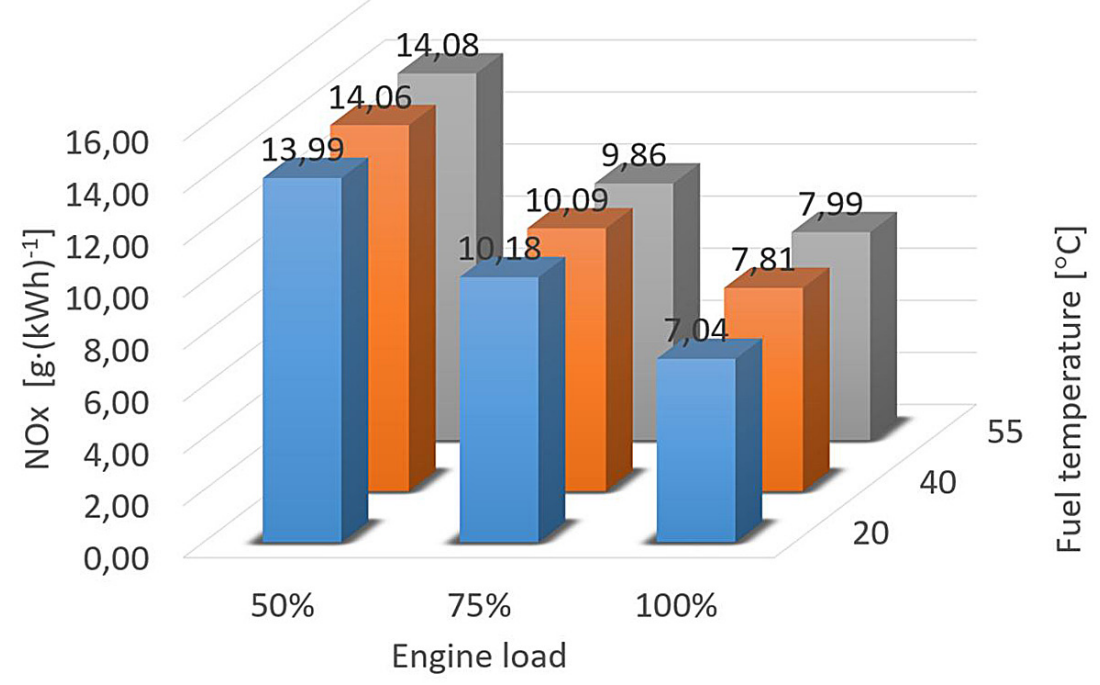

Fig. 2. Changes in specific $\mathrm{NO}_{\mathrm{x}}$ emissions from individual phases of the $\mathrm{D} 1$ test according to ISO $8178-4$ caused by variations in engine fuel supply temperature and load 


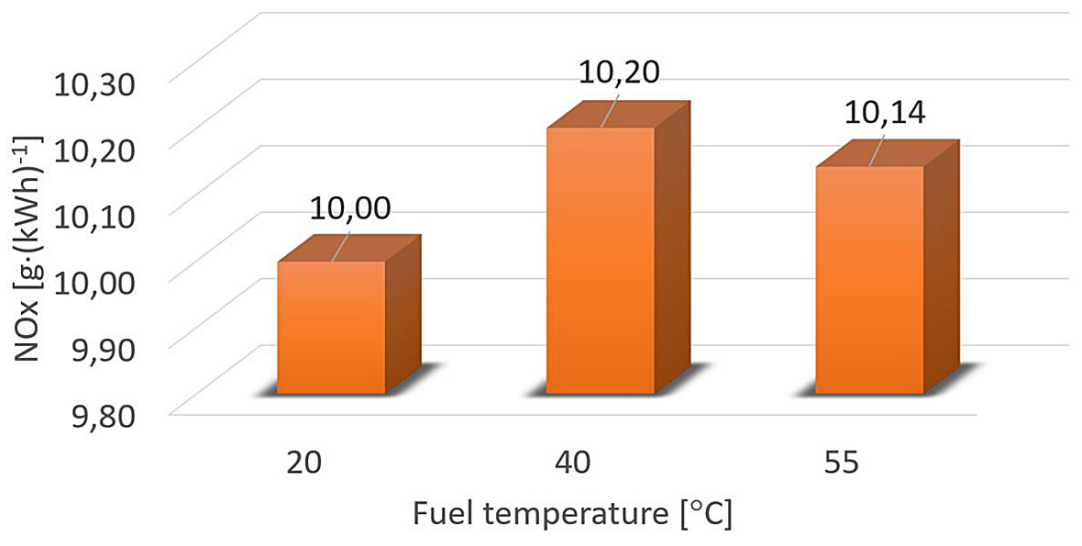

Fig. 3. Specific $\mathrm{NO}_{x}$ emissions from the $\mathrm{D} 1$ test according to ISO 8178-4 obtained at different fuel temperatures.

\section{CONCLUSION}

On the basis of the results obtained, the following can be stated:

1. Regardless of the temperature of the diesel fuel supplied to the engine injection system, an increase in the engine load results in a significant reduction in specific $\mathrm{NO}_{\mathrm{x}}$ emissions.

2. Only when the engine was running at a load of $75 \%$ of the nominal torque, the beneficial effect of an increase in the fuel temperature on the $\mathrm{NO}_{\mathrm{x}}$ emissions was found. However, the increase in the fuel temperature from $20^{\circ} \mathrm{C}$ to $55^{\circ} \mathrm{C}$ resulted in a reduction of $\mathrm{NO}_{\mathrm{x}}$ by only $3 \%$.

3. When the engine was running with both a lower and a higher load, an increase in the fuel temperature resulted in a simultaneous rise in specific $\mathrm{NO}_{\mathrm{x}}$ emissions, even by $14 \%$.

4. On the basis of the above, it must be concluded that preheating of diesel oil cannot be an effective method of reducing the $\mathrm{NO}_{x}$ emissions from the engines running on standard diesel fuel.

\section{Acknowledgement}

Publication is funded by the Polish National Agency for Academic Exchange under the International Academic Partnerships Programme from the project „Organization of the $9^{\text {th }}$ International Scientific and Technical Conference entitled Environmental Engineering, Photogrammetry, Geoinformatics - Modern Technologies and Development Perspectives".

\section{REFERENCES}

1. Blakeman P.G., Chiffey A.F., Phillips P.R., Twigg M.V., Walker. A.P. 2003. Developments in Diesel Emission Aftertreatment Technology. SAE Technical Papers. https://doi.org/10.4271/2003-01-3753.

2. Colliou T., Lavy J., Martin B., Chandès K., Pichon G., Pierron L. 2004. Coupling of a NOx Trap and a CDPF for Emission Reduction of a 6-Cylinder HD Engine. SAE Technical Papers, no. 724. https://doi. org/10.4271/2004-01-1945.

3. Conway R., Chatterjee S., Beavan A., Lavenius M., Viswanathan S., Walker A., Rawson S. 2005. Combined SCR and DPF Technology for Heavy Duty Diesel Retrofit. SAE Technical Papers, no. 724. https://doi.org/10.4271/2005-01-1862.

4. Czerwinski, J., Zimmerli Y., Meyer M., Kasper M. 2008. A Modern HD-Diesel Engine with Rapeseed Oil,DPF and SCR. SAE Technical Papers 2008 (724): 776-90. https://doi.org/10.4271/2008-01-1382.

5. Gracz W. 2018. Emisja gazów spalinowych i sprawność energetyczna wielopaliwowego agregatu kogeneracyjnego w biogazowniach do $40 \mathrm{~kW}$ (in Polish), Ph.D. Thesis. Instytut TechnologicznoPrzyrodniczy, Falenty.

6. Gysel N., Karavalakis G., Durbin T., Schmitz D., Cho A. 2014. Emissions and Redox Activity of Biodiesel Blends Obtained from Different Feedstocks from a Heavy-Duty Vehicle Equipped with DPF/ SCR Aftertreatment and a Heavy-Duty Vehicle without Control Aftertreatment. SAE Technical Papers. https://doi.org/10.4271/2014-01-1400.

7. Hochhauser A.M. 2009. Review of Prior Studies of Fuel Effects on Vehicle Emissions. SAE Technical Papers 2 (1): 541-67. https://doi. org/10.4271/2009-01-1181.

8. Hosoya M., Kawada Y., Sato S., Shimoda M. 2007. The Study of NOx and PM Reduction Using Urea Selective Catalytic Reduction System for Heavy 
Duty Diesel Engine. SAE Technical Papers 2007 (724). https://doi.org/10.4271/2007-01-1576.

9. Hountalas, D.T., Mavropoulos G.C., Zannis T.C., Mamalis S.D. 2006. Use of Water Emulsion and Intake Water Injection as NOx Reduction Techniques for Heavy Duty Diesel Engines. SAE Technical Papers 2006 (724). https://doi. org/10.4271/2006-01-1414.

10. Kawano D., Ishii H., Goto Y., Noda A., and Aoyagi Y. 2006. Application of Biodiesel Fuel to Modern Diesel Engine. SAE Technical Papers, no. 724. https://doi.org/10.4271/2006-01-0233.

11. Kleinová, A., Vailing I., Lábaj J., Mikulec J., Cvengroš J. 2011. Vegetable Oils and Animal Fats as Alternative Fuels for Diesel Engines with Dual Fuel Operation. Fuel Processing Technology. https://doi. org/10.1016/j.fuproc.2011.05.018.

12. Kono N., Kobayashi Y., Takeda H. 2005. Fuel Effects on Emissions from Diesel Vehicles Equipped with Advanced Aftertreatment Devices. SAE Technical Papers, no. 724. https://doi. org/10.4271/2005-01-3700.

13. Kouremenos D. A., Hountalas D.T., Binder K.B. 2001. The Effect of EGR on the Performance and Pollutant Emissions of Heavy Duty Diesel Engines Using Constant and Variable AFR. SAE Technical Papers 2001 (724). https://doi. org/10.4271/2001-01-0198.

14. Mizushima N., Sato S., Kawano D., Saito A., Takada Y.. 2012. A Study on NOx Emission Characteristics When Using Biomass-Derived Diesel Alternative Fuels. SAE International Journal of Fuels and Lubricants 5 (2): 892-99. https://doi. org/10.4271/2012-01-1316.

15. Ohashi N., Nakatani K., Asanuma T., Fukuma T., Matsubara H., Sobue Y., Watanabe M.. 2008. Development of Next-Generation NOx Reduction System for Diesel Exhaust Emission. SAE Technical Papers 2008 (724). https://doi.org/10.4271/2008-01-0065.

16. Okamoto K., Kohakura M., Kaneko T., Fukuda K., Furui K., Okada M., Tsuchihashi K., et al. 2010. Impact Study of High Biodiesel Blends on Exhaust Emissions to Advanced Aftertreatment Systems. SAE Technical Papers. https://doi. org/10.4271/2010-01-1292.

17. Parthiban E., Jain A.. 2019. Development of Diesel Particulate NOx Reduction DPNR System for Simultaneous Reduction of PM and NOx in Diesel Engines. SAE International 1, 3-9. https://doi.
org/10.4271/2019-28-2554.Abstract.

18. Piaseczny L., Władyka W. 2008. Effects of the thermal activation of fuel on energy parameters and toxicity of combustion gases in the marine diesel engine; Journal of Polish Cimac, Vol 3, No 1.

19. Pielecha I. 2001. Termodynamiczne aspekty koncepcji obniżania emisji tlenków azotu w silnikach wysokoprężnych (in Polish); Journal of Kones, Combustion Engines, Vol 8, No 3-4.

20. Ranjith V.V., Thanikaikarasan S. 2019. Prediction of Exhaust Gas Emission Characteristics Using Neem Oil Blended Bio-Diesel in Diesel Engine. Materials Today: Proceedings. https://doi.org/10.1016/j. matpr.2019.07.706.

21. Saito S., Shinozaki R., Suzuki A., Jyoutaki H., Takeda Y.. 2003. Development of Urea-SCR System for Commercial Vehicle - Basic Characteristics and Improvement of NOx Conversion at Low Load Operation. SAE Technical Papers, no. 724. https:// doi.org/10.4271/2003-01-3248.

22. Timothy J. 2014. Vehicular Emissions in Review. SAE International Journal of Engines 7 (3). https:// doi.org/10.4271/2014-01-1491.

23. Tsukamoto Y., Nishioka H., Imai D., Sobue Y., Takagi N., Tanaka T., Hamaguchi T.. 2012. Development of New Concept Catalyst for Low CO2 Emission Diesel Engine Using NOx Adsorption at Low Temperatures. SAE Technical Papers. https:// doi.org/10.4271/2012-01-0370.

24. Tsumagari I., Hirabayashi H., Takenaka Y., Hosoya M., Shimoda M.. 2006. Study of 2-LEG NOx Storage-Reduction Catalyst System for HD Diesel Engine. SAE Technical Papers, no. 724. https://doi. org/10.4271/2006-01-0211.

25. Uekusa T., Enoki K., Fujita T., Tanaka Y., Shibuya H., Nakada T.. 2003. A New NOx Reduction Catalyst System for Diesel Engine with High Sulfur Tolerance. SAE Technical Papers, no. 724. https://doi. org/10.4271/2003-01-3241.

26. Veltman M. K.,. Karra P.K, Kong S.C. 2009. Effects of Biodiesel Blends on Emissions in Low Temperature Diesel Combustion. SAE Technical Papers. https://doi.org/10.4271/2009-01-0485.

27. Wu Y., Ferns J., Li H., Andrews G. 2017. Investigation of Combustion and Emission Performance of Hydrogenated Vegetable Oil (HVO) Diesel. SAE International Journal of Fuels and Lubricants 10 (3). https://doi.org/10.4271/2017-01-2400. 